\title{
Białka z rodziny Vps13 - od funkcji molekularnej do patogenezy chorób neurodegeneracyjnych
}

\section{Joanna Kamińska}

\section{Damian Kołakowski}

Instytut Biochemii i Biofizyki PAN, Warszawa

Instytut Biochemii i Biofizyki PAN, ul. Pawińskiego 5a, 02-106 Warszawa; tel.: (22) 592 13 16, e-mail: kaminska@ibb.waw.pl

Artykuł otrzymano 25 maja 2018 r.

Artykuł zaakceptowano 16 lipca 2018 r.

Słowa kluczowe: choroby rzadkie, neurodegeneracja, białka rodziny Vps13, pląsawica-akantocytoza, zespół Cohena, miejsca kontaktu błon

Wykaz skrótów: aa - aminokwas; ChAc (ang. chorea-acanthocytosis) - pląsawica-akantocytoza; CL - kardiolipina; CPY - karboksypeptydaza Y; ER (ang. endoplasmic reticulum) - siateczka endoplazmatyczna; ERMES (ang. ER mitochondria encounter structure) - miejsca kontaktu błon ER i mitochondriów; FFAT - motyw dwóch fenyloalanin w ciągu aminokwasów kwaśnych; LPA - kwas lizofosfatydowy; NVJ (ang. nuclear vacuolar junction) - miejsca kontaktu błon wakuoli i jądra; PA - kwas fosfatydowy; PH (ang. plekstrin homology) - domena o homologii do plekstryny; PI - fosfatydyloinozytol; $\mathrm{PI}(3) \mathrm{P}-3$ fosforan fosfatydyloinozytolu; $\mathrm{PI}(3,4,5) \mathrm{P}_{3}-3,4,5$ trifosforan fosfatydyloinozytolu; PI(4)P - 4 fosforan fosfatydyloinozytolu; $\mathrm{PI}(4,5) \mathrm{P}_{2}-4,5$ bisfosforan fosfatydyloinozytolu; PM (ang. plasma membrane) - błona komórkowa; TGN (ang. trans Golgi network) - cysterny trans aparatu Golgiego; vCLAMP (ang. vacuole and mitochondria patch) - miejsca kontaktu błon wakuoli i mitochondriów; Vps (ang. vacuolar protein storting) - białka sortujące do wakuoli

Podziękowania: Badania prowadzone przez autorów niniejszej pracy przeglądowej są finansowane ze środków na naukę przyznanych przez Narodowe Centrum Nauki na realizację w latach 2016-2019 projektu UMO-2015/19/B / NZ3/01515 oraz przez Instytut Biochemii i Biofizyki PAN.

\section{STRESZCZENIE}

G rupa białek Vps (ang. vacuolar protein sorting) zaangażowanych w transport do waku$\exists$ oli została odkryta u drożdży Saccharomyces cerevisiae. Wśród białek Vps, jest rodzina Vps13, której przedstawiciele występują u organizmów z różnych grup systematycznych. U drożdży jest jedno białko Vps13, a u ludzi są cztery Vps13 - hVps13A-D. Są to białka duże, o charakterystycznej budowie domenowej. Mutacje w genach $h$ VPS13 są powiązane z rzadkimi chorobami neurodegeneracyjnymi: pląsawicą-akantocytozą ( $h V P S 13 A)$, zespołem Cohena ( $h V P S 13 B / C O H 1)$, usposabiają do wczesnej choroby Parkinsona ( $h V P S 13 C)$ i prowadzą do ataksji/kurczowego porażenia kończyn (hVPS13D). Brak jasnych kryteriów diagnostycznych, szerokie spektrum niespecyficznych objawów powodują, że chorzy z neurodegeneracją są często źle diagnozowani i trudno jest określić liczbę pacjentów z mutacjami w genach $h$ VPS13. Istotność białek z rodziny Vps13 dla zdrowia ludzi nakierowuje badania na poznanie ich funkcji molekularnej, która jest nieznana. Badania najczęściej prowadzone są w modelowych układach doświadczalnych, w których wywołano deficyt tych białek na drodze delecji lub wyciszenia ekspresji odpowiednich genów oraz na komórkach pochodzących od pacjentów. Opisano wiele zmian na poziomie komórkowym wywołanych brakiem białek Vps13, które dotyczą transportu komórkowego białek między cysternami aparatu Golgiego, błoną komórkową i endosomami, funkcjonowania mitochondriów i organizacji cytoszkieletu komórkowego, głównie aktynowego. Nie wiadomo jednakże, które zmiany są zmianami pierwotnymi, a które wtórnymi, kompensacyjnymi. Ostatnio badania na drożdżach pokazały Vps13, jako białko zlokalizowane w miejscach kontaktu błon, strukturach zapewniających wymianę metabolitów między różnymi organellami. Taka lokalizacja wydaje się być kluczowa dla funkcji Vps13. Na podstawie danych literaturowych proponujemy hipotezę o aktywnym udziale białek Vps13 w wymianie lipidów między błonami organelli w miejscach kontaktu błon, która tłumaczy większość fenotypów obserwowanych przy braku białka Vps13.

\section{WPROWADZENIE}

Białka z grupy Vps (ang. vacuolar protein sorting) zostały zidentyfikowane $\mathrm{u}$ drożdży Saccharomyces cerevisiae, jako te, których deficyt powoduje zmianę transportu hydrolazy wakuolarnej, karboksypeptydazy Y (CPY). W mutantach vps CPY nie dociera do wakuoli, lecz ulega sekrecji na zewnątrz komórki [1]. Jednym z wielu drożdżowych białek Vps jest Vps13, będące pierwszym opisanym białkiem z rodziny Vps13. Jednakże białka Vps13 są dość dobrze zachowane w ewolucji i można je znaleźć w organizmach należących do wielu grup systematycznych. U ludzi, szczurów i myszy są cztery homologi oznaczone Vps13 A-D [2]. Najwięcej białek z tej rodziny zidentyfikowano u pierwotniaków z rodzaju Dictyostelium [3].

Mutacje w genach kodujących białka Vps13 wiąże się z chorobami neurodegeneracyjnymi. Te w hVPS13A i $h$ VPS13B/COH1 wywołują odpowiednio pląsawicę-akantocytozę i zespół Cohena. W genach $h$ VPS13C i $h$ VPS13D, kodujących dwa pozostałe białka, również odkryto mutacje, które ostatnio powiązano z chorobami neurodegeneracyjnymi, odpowiednio chorobą Parkinsona i ataksją/kurczowym porażeniem kończyn. Pomimo istotnego znaczenia białek z tej rodziny dla zdrowia ludzi, ich funkcja molekularna nadal pozostaje nieznana. Najlepiej scharakteryzowane są fenotypy na poziomie molekularnym związane z brakiem białka Vps13 w modelu drożdżowym. Poniższy tekst opisuje choroby i problemy związane z ich leczeniem, jak również porządkuje dotychczasową wiedzę dotyczącą wpływu mutacji w genach VPS13 na funkcjonowanie komórek. Przedstawiono także drożdże, jako prosty i wygodny model do badania funkcji białek Vps13. W oparciu o zebrane dane literaturowe, głównie z badań na drożdżach, zaproponowano hipotetyczną funkcję białka Vps13 związaną z jego lokalizacją w miejscach kontaktu błon różnych organelli, struktur istotnych dla prawidłowego funkcjonowania komórki. 


\section{BUDOWA BIAŁEK VPS13}

Białka Vps13 charakteryzują się dużymi rozmiarami, zbudowane są z ponad 3 tysięcy aminokwasów (aa). Wśród tej grupy białko drożdżowe jest najmniejsze, gdyż składa się z 3144 aa, a dla porównania ludzkie hVps13D ma 4388 aa (Ryc. 1). Drożdżowe białko Vps13 jest najbardziej podobne do ludzkiego hVps13A, zwanego też choreiną. Podobieństwo sekwencji aminokwasowej na całej długości białek wynosi $40 \%$, a identyczność jest na poziomie $22 \%$. Pośród ludzkich homologów hVps13A jest najbardziej podobne do hVps13C. Podobieństwo i identyczność między nimi wynoszą odpowiednio 40\% i 60\% [2]. Analiza białek Vps13 wykazuje, że największe podobieństwo występuje w rejonach $\mathrm{N} \mathrm{i}$ C końca (Ryc. 1), w obrębie poszczególnych domen.

Analizy bioinformatyczne pokazały, że N-końcowe fragmenty białek Vps13 są charakterystyczne dla białek tej rodziny i zawierają takie domeny jak Chorein_N, VPS13 i VPS13_mid_rpt, z wyjątkiem białka hVps13B (zwanego też Coh1), u którego na N-końcu zidentyfikowano tylko domenę Chorein_N (Ryc. 1). Niewiele jest wiadomo na temat funkcji tych domen. Fragment niosący domeny Chorein_N i VPS13 z drożdżowego Vps13 wiąże się do syntetycznych liposomów wzbogaconych o kwas fosfatydowy (PA) i z mniejszym powinowactwem do zawierających 4,5 difosforan fosfatydyloinozytolu $\left(\mathrm{PI}(4,5) \mathrm{P}_{2}\right)$ lub 4 fosforan fosfatydyloinozytolu (PI(4)P) [4]. Natomiast dla domeny Chorein_N z ludzkiego hVps13A zaproponowano, że może być ona istotna dla dimeryzacji, na co wskazuje obecność suwaka leucynowego w jej obrębie (aa 3-119) [5]. Opisano także oddziaływanie in vitro między oczyszczonym fragmentem hVps13A (aa 1-604, obejmujący domeny Chorein_N, Vps13 i fragment domeny VPS13_mid_rpt, Ryc. 1) i domeną C2B z białka Syt1, będącego błonowym białkiem promującym fuzje błon, należącym do grupy białek typu SNARE. Wprawdzie nie udało się pokazać in vivo formowania kompleksu pomiędzy białkami pełnej długości, jednakże Vps13A izolowano z frakcji komórek linii PC12 wyprowadzonej z guza chromochłonnego nadnercza szczura, w której również znajduje się białko Syt1 [5]. W N-końcowym fragmencie omawianych białek w domenie VPS13_mid_rpt znajduja się powtórzenia sekwencji aminokwasowej $\mathrm{P}-\mathrm{X}_{4}-\mathrm{P}-\mathrm{X}_{13-17}-\mathrm{G}$, gdzie P-prolina, X-dowolny aminokwas, G-glicyna.

Sekwencja białek Vps13 w środkowej części jest zmienna. $\mathrm{W}$ hVps13A i hVps13C w tym rejonie znajdują się motywy typu FFAT (dwie fenyloalaniny w ciągu aminokwasów kwaśnych). Motywy te wiążą domeny MSP białek VAP-A/B, tj. transbłonowych białek siateczki śródplazmatycznej (ER, ang. endoplasmic reticulum) uczestniczących w tworzeniu miejsc kontaktu błon. Motywy FFAT z hVps13A i hVps13C prawdopodobnie wiążą białka VAP-A/B [6]. Drożdżowy Vps13 posiada motyw FFAT, sekwencję EFFDA (aa 1521-1525), jednakże dotychczas nie stwierdzono, czy wiąże się do drożdżowych homologów białek VAP, Scs2 i Scs22.

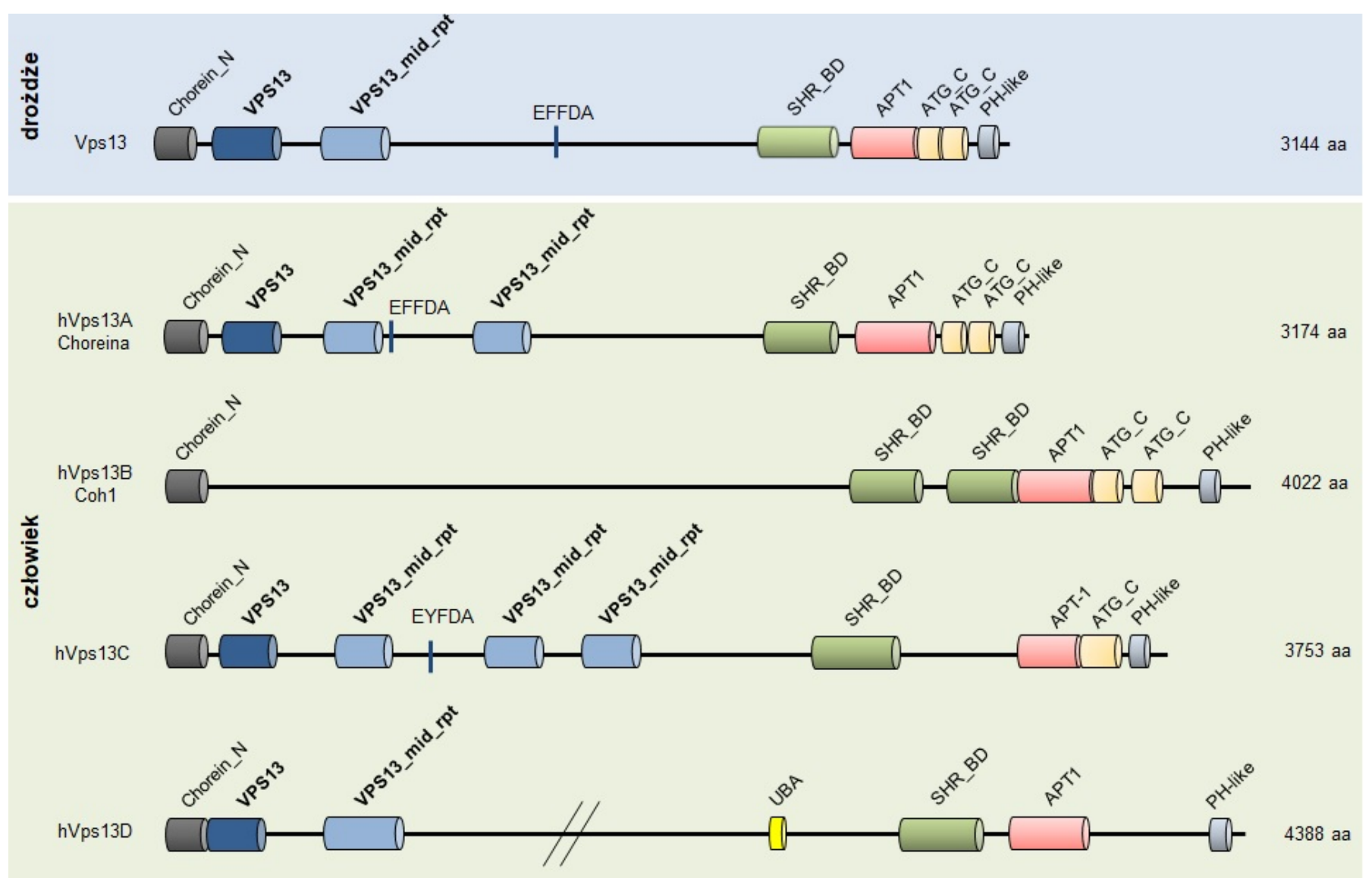

Rycina 1. Budowa domenowa drożdżowego białka Vps13 i ludzkich białek hVps13A-D. 
C-końcowe fragmenty białek Vps13 zawierają domeny znajdowane również w innych białkach, takie jak: SHR_BD, APT1 i ATG_C. Domena SHR_BD została opisana u roślin, w białku nazwanym SHRUBBY. SHRUBBY należy do grupy białek zaangażowanych w sortowanie białek do wakuoli, a domena SHR_BD jest odpowiedzialna za wiązanie czynnika transkrypcyjnego SHR, regulującego wzrost korzeni [7]. Fragment odpowiadający domenie SHR_BD i rejonowi pomiędzy domenami SHR_BD i APT1 (2247-2599 aa), w drożdżowym Vps13, wykazuje interakcję z mitochondrialnym białkiem Mcp1, które umożliwia rekrutowanie Vps13 do miejsc kontaktu błon pomiędzy wakuolą, a mitochondriami [8]. Domena APT1 pierwszy raz została pokazana u kukurydzy, w białku związanym z aparatem Golgiego, jako niezbędna do wzrostu łagiewki pyłkowej [9]. Dla domeny APT1 zidentyfikowanej w białku Atg2, biorącym udział w autofagii, wykazano, że może ona wiązać PI(3)P [10]. Podobną specyfikę wiązania ma fragment Vps13 z drożdży zawierający domeny SHR_BD i APT1 [11]. Domena SHR_BD wiąże wiele różnych pochodnych fosforanowych fosfatydyloinozytolu (PI), a połączone domeny SHR_BD i APT1 specyficznie wiążą 3 fosforan fosfatydyloinozytolu (PI(3)P). Oznaczać to może, że domena APT1 nadaje domenie SHR_BD specyficzność wiązania względem wybranej pochodnej PI [11]. Domena ATG_C jest powtórzona w niektórych białkach Vps13 (Ryc. 1). Takie ułożenie domen w C-końcu jak w białkach Vps13 jest też w C-końcowym fragmencie wspomnianego wyżej białka Atg2. Dodatkowo białka Vps13 mają domenę podobną do domeny PH (ang. plekstrin homology), domenę PH-like [12,13]. Domeny PH mają zdolność do wiązania bi i tri fosforanowych pochodnych PI, a domeny PH-like mogą wiązać zarówno lipidy, białka jak i umożliwiają wiązanie obu tych typów molekuł naraz. Wśród białek oddziałujących z domenami PH-like bardzo często spotykane są białka wiążące nukleotydy guaninowe, tzw. GTPazy jak np. Arf1 [14]. C-końcowy fragment białka Vps13 z drożdży, zawierający drugie powtórzenie domeny ATG_C i domenę PH-like, wiąże, podobnie jak N-końcowy fragment, $\mathrm{PI}(4,5) \mathrm{P}_{2}[4]$. Natomiast $\mathrm{Vps} 13 \mathrm{D}$ posiada dodatkowo domenę UBA, czym odróżnia się od pozostałych białek Vps13. Domeny UBA z różnych białek wiążą ubikwitynę. Również domena UBA z Vps13D wiąże się do łańcuchów ubikwitynowych, złożonych z czterech ubikwityn utworzonych przez połączenie C-końcowej glicyny jednej cząsteczki ubikwityny z resztą lizyny 63 poprzedniej ubikwityny [15]. Wskazuje to, że Vps13D może brać udział w przekazywaniu sygnału przez ubikwitynę.

Wymienione cechy budowy białek Vps13, takie jak duże rozmiary, zdolność wielu domen do wiązania lipidów, czy interakcje z białkami błonowymi różnych organelli umożliwiają im funkcjonowanie $\mathrm{w}$ miejscach kontaktów błon. Dane wskazujące na tę lokalizację zostaną opisane w dalszej części pracy.

\section{CHOROBY ZWIAZZANE Z MUTACJAMI W GENACH VPS13}

Zidentyfikowano mutacje we wszystkich czterech ludzkich genach $h V P S 13$. Najwcześniej znaleziono mutacje $\mathrm{w}$ genach $h V P S 13 A$ [16] i $h V P S 13 B / C O H 1$, [17] które prowa- dzą do rozwoju chorób genetycznych, dziedziczonych autosomalnie recesywnie, odpowiednio pląsawicy-akantocytozy (ChAc, ang. Chorea-acanthocytosis) i zespołu Cohena. Obie choroby klasyfikowane są jako choroby rzadkie. Pląsawica-akantocytoza to choroba dotykającą ludzi dorosłych. Szacuje się, że na świecie jest około 1000 chorych, w tym kilku w Polsce [18-21]. ChAc charakteryzuje się postępującymi problemami motorycznymi, ruchami mimowolnymi, trudnościami w mówieniu i przełykaniu [22]. Obserwuje się też zmiany osobowościowe [22]. Za zmiany te odpowiada postępująca neurodegeneracja, która prowadzi ostatecznie do śmierci chorego [23]. Chorzy wykazują podwyższony poziom kinazy keratynowej $\mathrm{w}$ surowicy. U części pacjentów obserwuje się akantocyty, czerwone krwinki o nieregularnych kształtach $[22,23]$. Podobne objawy opisuje się $\mathrm{w}$ mysim modelu choroby. Wraz z wiekiem, u myszy pozbawionych funkcjonalnej choreiny dochodzi do zmian motoryki oraz pojawiają się akantocyty; w prążkowiu mózgu (łac. striatum) obumierają neurony, a samce myszy dodatkowo są bezpłodne [24].

Zespół Cohena to choroba, która zaczyna rozwijać się już w wieku dziecięcym. W literaturze po raz pierwszy została omówiona w 1973 roku [25], a dotychczas zarejestrowano ok. 200 przypadków tej choroby na całym świecie. Najliczniej występuje w populacji fińskiej i grupie etnicznej Amiszów [26]. Charakterystyczną cechą dla tego zespołu jest małogłowie. Pacjenci mają mniejsze mózgi, o prawidłowej budowie. Wpływ białka hVps13B na wielkość mózgu wiązany jest $\mathrm{z}$ jego wpływem na długość aksonu komórek nerwowych. Jak wykazano dla neuronów z hipokampu szczura, wyciszenie genu VPS13B powoduje spadek długości aksonu o ok. 40\% [27]. U dzieci z zespołem Cohena obserwuje się również obniżone napięcie mięśniowe, wiotkość stawów i postępujące pogarszanie się wzroku. Dzieci te są także opóźnione $\mathrm{w}$ rozwoju psychomotorycznym i mają ograniczone zdolności intelektualne. $Z$ mutacjami w genie hVPS13B łączy się też autyzm $[28,29]$. Choroby wywołane mutacjami w $h V P S 13 C$ i $D$ są również rzadkie. Mutacje $\mathrm{w}$ hVPS13C związane są z wczesnym pojawieniem się choroby Parkinsona [30]. Dopiero w ostatnim czasie opisano mutacje w hVPS13D, które powodują wczesne pojawienie się objawów motorycznych związanych z przykurczem kończyn. U dzieci obserwuje się opóźnienia rozwoju motorycznego i mowy $[31,32]$.

Zarówno w przypadku genu $h V P S 13 A$, jak i $h V P S 13 B$, mutacje zidentyfikowane u pacjentów to głównie mutacje zmieniające ramkę odczytu i generujące przedwczesny kodon STOP, czy mutacje typu nonsens. W skutek tych mutacji w komórkach brak jest odpowiedniego białka. Opisano też mutacje zaburzające dojrzewanie transkryptu [12]. Niewiele jest mutacji, których skutkiem są pojedyncze substytucje reszt aminokwasowych $\mathrm{w}$ białku. Stanowią one w każdym z przypadków poniżej 10\% mutacji. Znanych jest tylko 6 mutacji w VPS13C, z czego jedna jest mutacją zmieniająca pojedynczą resztę aminokwasową [12]. Natomiast dla $h V P S 13 D$, w dwóch pracach, przedstawione są $32 \mathrm{mu}-$ tacje, z których większość to mutacje powodujące substytucje reszt aminokwasowych [31,32]. Fakt, że w hVPS13D opisano tylko mutacje prowadzące do substytucji wynika prawdopodobnie z tego, że komórki nie tolerują braku pro- 
duktu genu $h V P S 13 D$. W organizmach modelowych, takich jak myszy czy muszka owocowa, delecje VPS13D są letalne [31]. Mutacje znalezione u pacjentów w genach $h V P S 13 A-$ -D są rozproszone po całym genie [2,12,30-32]. Oznacza to, że do prawidłowego funkcjonowania Vps13 niezbędne są wszystkie jego domeny.

\section{PROBLEMY DIAGNOSTYCZNE I TERAPEUTYCZNE}

Statystyka dotycząca częstotliwości występowania chorób związanych z deficytem białek Vps13 jest zaniżona. Jest to wynikiem problemów z postawieniem poprawnej diagnozy na podstawie obrazu klinicznego. Pacjenci z ChAc są diagnozowani między innymi, jako chorzy na chorobę Parkinsona, ze względu na zespół objawów charakterystycznych dla tej jednostki chorobowej. Problemem jest też fakt, że ta choroba rozwija się przez wiele lat, a lekarze neurolodzy nie widzą pacjenta w całym przebiegu jego choroby, tylko w pewnym okienku czasowym. Oznacza to, że nie obserwują wszystkich objawów, które są różne w kolejnych etapach choroby. Inny problem obrazuje przypadek $\mathrm{z}$ populacji japońskiej, w którym opisano jedną mutację $\mathrm{w}$ hVPS13A, prowadzącą do zmiany w dojrzewaniu mRNA i skutkującą brakiem fragmentu domeny APT1 kodowanego przez eksony 60 i 61 [16]. Pomimo obecności tej samej mutacji, pacjenci zaczynają chorować w różnym wieku i mają zróżnicowane objawy kliniczne. Podobnie, wprowadzenie analogicznej mutacji u myszy powoduje różne nasilenie objawów [33]. Pokazuje to, że zarówno środowisko jak i tło genetyczne mogą mieć znaczący wpływ na pojawienie się i rozwój choroby. Diagnoza stawiana jest więc zazwyczaj różnicowo, przez wykluczenie innych jednostek chorobowych. W niektórych ośrodkach diagnozę weryfikuje się sprawdzając poziom białka choreiny w komórkach krwi pacjentów. Ta metoda diagnostyczna jest używana, gdyż stwierdzono, że u większości pacjentów z ChAc nie ma ekspresji choreiny. Nie jest to jednak test ostateczny. W celu postawienia pewnej diagnozy należy zsekwencjonować locus hVPS13A u pacjenta i wskazać mutację. Takich badań rutynowo się nie wykonuje ze względu na znaczną wielkość genu hVPS13A.

Oddzielną kwestią jest brak efektywnego leczenia [23]. Poza zespołem Cohena, który objawia się u dzieci, terapie rozpoczyna się u dorosłych pacjentów, gdy choroba dała już objawy kliniczne, chociaż rozwijała się od urodzenia. Ponadto, każdy z pacjentów jest w innym stadium rozwoju choroby, więc inny jest obraz kliniczny, inna jest odpowiednia dla niego terapia i warunki jej przeprowadzenia. Pojawia się także trudność w doborze parametru, który należałoby monitorować, jako najlepszy wskaźnik poprawy stanu zdrowia pacjenta w trakcie leczenia. Stosowane dotychczas jest jedynie leczenie objawowe i paliatywne. Nie istnieje standard określający, który z objawów należy eliminować w pierwszej kolejności. Niektóre terapie dotychczas stosowane są bardzo drogie i w wielu krajach pacjenci nie mogą być nimi objęci ze względów ekonomicznych. W kilku przypadkach pląsawicy-akantocytozy skuteczna okazała się głęboka stymulacja mózgu, która pomogła ograniczyć u pacjentów m.in. pląsawicę, lecz nie dała rezultatu w przypadku objawów parkinsonizmu [23]. Istotne wydają się także kwestie psychiatryczne. Wielu pacjentów cierpiących na pląsawicę- -akantocytozę popada w depresję i podejmuje próby samobójcze. We wszystkich opisanych powyżej chorobach pacjenci wymagają opieki do końca życia. Realizacja tego wymogu generuje nie tylko wysokie koszty ekonomiczne, ale także często wyłączenie z życia społecznego i zawodowego kogoś ze zdrowych członków rodziny. Konieczne jest opracowanie metod diagnostycznych i terapii co w przypadku chorób rzadkich napotyka na przeszkodę, jaką jest niewielka grupa pacjentów, która nie spełnia wymogów statystycznych. Powoduje to, że nie jest możliwe przeprowadzenie standardowych badań klinicznych. Dodatkowo, nie da się opracowywać wyników z użyciem standardowych testów statystycznych, służących do oceny zmian ilościowych. Niezbędne jest więc prowadzenie badań podstawowych, które pomogą w zdefiniowaniu patogenezy chorób związanych z brakiem białek Vps13 i opracowanie terapii celowanej w konkretny proces komórkowy.

\section{FUNKCJA BIAŁEK VPS13}

Molekularna funkcja białek Vps13 nie jest znana. Poniżej opisano wyniki badań mających na celu scharakteryzowanie działania białek Vps13 w różnych modelowych układach badawczych. Obecnie w badaniach używa się erytrocytów i fibroblastów lub neuronów zróżnicowanych z fibroblastów pochodzących od pacjentów. Wykorzystuje się również organizmy modelowe takie jak drożdże, śluzowce Dictyostelium, muszka owocowa, czy ssaki jak szczur i mysz [12,23]. Dotychczasowe badania podstawowe umożliwiły zebranie częściowej wiedzy o funkcjonowaniu białek Vps13. Obejmują one wiele procesów komórkowych. Głównie opisywany jest udział białek Vps13 w transporcie białek między aparatem Golgiego, endosomami i błoną komórkową, w funkcjonowaniu mitochondriów oraz wpływ na funkcjonowanie cytoszkieletu aktynowego. Różnorodność fenotypów spowodowanych brakiem białek Vps13 może wskazywać na różnorodność ich funkcji. Jednakże istnieją przesłanki z prac nad Vps13 u drożdży, skłaniające do rozpatrywania Vps13, jako białka pełniącego pojedynczą funkcję w wielu lokalizacjach w komórce, co wpływa pośrednio na wiele procesów.

Vps13A

Główne zmiany obserwowane u pacjentów z ChAc dotyczą tkanki nerwowej i krwi. Natomiast przeciwciało rozpoznające choreinę wykrywa białko we wszystkich dotychczas badanych tkankach. Największe ilości choreiny występują w jądrach, śledzionie i nerkach. Choreina znajdowana jest także w ekstraktach uzyskanych $\mathrm{z}$ różnych fragmentów mózgu, a wzbogacenie tego białka obserwuje się we frakcji mikrosomalnej i synaptosomalnej neuronów. W barwieniach immunocytochemicznych neuronów z fragmentu kresomózgowia, przeciwciała wiążą się do struktur siateczkowatych w pobliżu jąder komórkowych, a w neuronach hipokampu wskazują na obecność choreiny głównie w cytoplazmie i strukturach włókien [34]. Brak konkretnej lokalizacji wewnątrzkomórkowej białka Vps13A nie daje odpowiedzi na pytanie o organellum, którego dysfunkcja mogłaby być przyczyną choroby. Opisywanych jest szereg zmian (przedstawionych poniżej) w komórkach z wyciszonym genem VPS13A lub tych po- 
chodzących od pacjentów. Nie wiadomo jednak, które z opisywanych fenotypów to zmiany pierwotne, wynikające bezpośrednio z braku białek Vps13, a które są zmianami wtórnymi spowodowanymi kompensacją przez komórkę pierwotnych defektów. Jedną ze zmian opisanych na

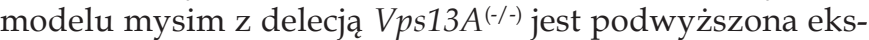
presja genu receptora kwasu gamma-aminomasłowego GABRG2 oraz genu białka kotwiczącego receptory GABA do cytoszkieletu postsynaptycznego. Sugeruje się, że efekt ten jest powodowany przez kompensacyjne działanie komórki w odpowiedzi na brak Vps13A [35]. Zaobserwowano obniżoną ekspresję genu $V A M P 8$, który koduje białko z rodziny syntaksyn, niezbędne do fuzji pęcherzyków sekrecyjnych z błona komórkową, jak również spadek uwalniania dopaminy z komórek PC12 pozbawionych genu VPS13A [36]. Natomiast zmiany w wyglądzie czerwonych krwinek u pacjentów z pląsawicą-akantocytozą, wiąże się z zaburzeniami w polimeryzacji cytoszkieletu aktynowego. Proporcja aktyny globularnej do spolimeryzowanej $\mathrm{w}$ ekstraktach pochodzących z erytrocytów pacjentów przesunięta jest $\mathrm{w}$ kierunku monomerów aktyny. Barwienia falloidyną erytrocytów i fibroblastów pacjentów, pokazują w nich mniej filamentów aktynowych niż w komórkach od ludzi zdrowych [37]. Choreina oddziałuje z $\beta$-aktyną i $\beta$-adducyną. $\beta$-adducyna jest białkiem czapeczki na końcu filamentu aktynowego, które zapobiega dołączaniu i odłączaniu monomerów aktynowych. Promuje też wiązanie spektryny do filamentów aktynowych w erytrocytach. Duża ilość $\beta$-adducyny występuje w mózgu, gdzie wykrywana jest w synapsach. Oddziaływanie $\beta$-adducyny i $\beta$-aktyny $z$ choreiną jest istotne dla ich stabilizacji. W erytrocytach pacjentów z ChAc wykrywane jest znacznie mniej $\beta$-aktyny i formy $1 \beta$-adducyny [38]. Brak choreiny wpływa nie tylko na zmiany w cytoszkielecie aktynowym. Zmiany dotyczą też innych typów szkieletu komórkowego [39]. Wykazano oddziaływanie choreiny z a-tubuliną i deacetylazą HADC6 [40]. Jednym ze sposobów działania choreiny na cytoszkielet w erytrocytach, jest wpływ na kinazę PI3K klasy I. Kinazy tej klasy są heterodimerami składającymi się z dwóch podjednostek - katalitycznej i regulatorowej, przeprowadzającymi reakcję fosforylacji $\mathrm{PI}(4,5) \mathrm{P}_{2}$ do 3,4,5 trisfosforanu fosfatydyloinozytolu $\left(\mathrm{PI}(3,4,5) \mathrm{P}_{3}\right)[41]$. Opisano oddziaływanie choreiny z podjednostką regulatorową kinazy PI3K [37]. Brak tego oddziaływania powoduje, że w erytrocytach pacjentów obniżona jest aktywność kinazy PI3K klasy I i co za tym idzie spada poziom produkowanego przez nią $\mathrm{PI}(3,4,5) \mathrm{P}_{3}$. Dalszą konsekwencją jest niższa aktywność kolejnej kinazy w kaskadzie przekazywania sygnału, kinazy Rac1 [37]. Szlak PI $(3,4,5) \mathrm{P}_{3}$ - kinaza Rac1 - kinaza Pak1 aktywuje białko N-WASP, co prowadzi do aktywacji kompleksu Arp2/3. Aktywny kompleks Arp2/3 odpowiada za inicjacje polimeryzacji aktyny, stanowiąc centrum nukleacji dla powstającego filamentu aktynowego [42]. Szlak sygnałowy PI $(3,4,5) \mathrm{P}_{3}$ - kinaza Rac1 - kinaza Pdk1 odpowiada zaś za fosforylację białka BAD. Ufosforylowane białko BAD wiąże białka $\mathrm{Bcl} 2$ i Bax, co blokuje zapoczątkowanie apoptozy. Obniżenie fosforylacji BAD w komórkach erytrocytów od pacjentów z pląsawicą-akantocytozą powoduje zwiększenie depolaryzacji błony mitochondrialanej, fragmentowanie DNA i podwyższony poziom fosfatydyloseryny na powierzchni komórek, co jest sygnałem do apoptozy - programowanej śmierci komórek [37]. Innym efektem powiązanym z ograniczeniem aktywności kinazy PI3K w fibroblastach pacjentów z ChAc jest spadek poziomu białka Ora1, podjednostki kanału transportującego $\mathrm{Ca}^{2+}$ do wnętrza komórki i zmniejszony napływ jonów $\mathrm{Ca}^{2+}[43,44]$. Zmiany w aktywności kinazy PI3K są duże, jednakże wyciszenie VPS13A w szczurzych komórkach PC12 nie zmienia znacząco poziomu $\mathrm{PI}(3,4,5) \mathrm{P}_{3}$ w błonie komórkowej, zaobserwowano natomiast znaczący spadek poziomu PI(4)P [45]. Inną kinazą, której aktywność jest zmieniona u pacjentów z ChAc jest kinaza Lyn, z rodziny kinaz Src. Pobudzenie aktywności tej kinazy powoduje zmiany w oddziaływaniach białek błony komórkowej erytrocytów z cytoszkieletem, co również przyczynia się do powstawania akantocytów [46].

\section{Vps13B}

Niewiele jest badań nad molekularną funkcją białka hVps13B, zwanego też Coh1. Jest to białko aparatu Golgiego, potrzebne do jego organizacji. Brak hVps13B skutkuje fragmentacją aparatu Golgiego [47]. Postuluje się, że hVps13B jest białkiem efektorowym GTPazy Rab6, regulującej transport pęcherzyków z aparatu Golgiego i endocytozę [27]. Wpływ białka hVps13B na integralność aparatu Golgiego wiązany jest z defektem wzrostu aksonów obserwowanym u pacjentów. Obserwowane są też zmiany na poziomie glikozylacji białek $\mathrm{w}$ fibroblastach od pacjentów z zespołem Cohena, co jest zgodne z faktem, że hVps13B reguluje funkcjonowanie aparatu Golgiego, organellum, w którym zachodzi glikozylacja [48].

Vps13C

Podobnie jak w przypadku Vps13B, wiedza na temat działania hVps13C jest bardzo ograniczona. Badania $\mathrm{z}$ użyciem modelu mysiego pokazały, że najwyższy poziom ekspresji VPS13C jest w mózgu i w brunatnej tkance tłuszczowej. W komórkach adipocytów mysich, Vps13C lokalizuje się w ciałkach lipidowych i ma wpływ na ich wielkość oraz uwalnianie z nich kwasów tłuszczowych [49]. W adipocytach, Vps13C oddziałuje z galektyną-12, regulując jej stabilność, co wpływa na biogenezę komórek tłuszczowych [50]. Populacja pacjentów z polimorfizmem w genie $h V P S 13 C$ wykazuje zmiany w parametrach związanych z cukrzycą typu 2. Obniżona jest sekrecja insuliny stymulowana glukozą, co prowadzi do podwyższenia poziomu glukozy we krwi [51]. Ekspresja VPS13C u ssaków jest na wysokim poziomie w komórkach beta trzustki [51,52]. Pozbawienie myszy genu VPS13C istotnie podwyższa też poziom wapnia w komórkach stymulowanych glukozą oraz, podobnie jak u ludzi, upośledza sekrecję insuliny [53]. W komórkach ludzkich wykazano obecność białka hVps13C na izolowanych mitochondriach, jako związanego z ich zewnętrzną błoną. Jednak funkcja hVps13C w mitochondriach jest nieznana. Wiadomo jedynie, że wyciszenie hVPS13C skutkuje zmianami w ich morfologii tj. rozproszeniem w komórce, fragmentacją oraz zmianami w funkcjonowaniu - spadkiem potencjału błony mitochondrialnej, co w konsekwencji wzmaga mitofagię, proces wybiórczej degradacji uszkodzonych mitochondriów w lizosomach [30]. 
Vps13D

Badania pokazują, że zarówno u myszy jak i u muszki owocowej, delecja obu kopii genu VPS13D jest letalna. Wykorzystuje się więc układy eksperymentalne wyciszające VPS13D w wybranych tkankach, w różnych stadiach ich rozwoju. U muszki owocowej brak białka Vps13D w trakcie rozwoju prowadzi do zmian w budowie układu pokarmowego, co jest powiązane ze zmianami w podziałach mitochondriów [15]. Zmiany w morfologii mitochondriów są również obserwowane w centralnym układzie nerwowym. Obniżenie poziomu Vps13D w neuronach motorycznych prowadzi do zaburzenia transportu mitochondriów do dystalnych części aksonów. W fibroblastach pacjentów, podobnie jak u muszki, obserwuje się zmiany morfologii mitochondriów. Mitochondria komórek pacjentów są bardziej okrągłe, skupione, tworzą strukturę przypominającą obwarzanek i produkują mniej ATP [31].

\section{Vps13 U DROŻDŻY}

Komórki drożdży pozbawione genu VPS13 rosną w bogatych pożywkach wzrostowych porównywalnie do komórek kontrolnych. Poznane fenotypy wywołane brakiem Vps13 to zmiany na poziomie molekularnym. Pierwszą z nich jest zmiana transportu pęcherzykowego między cysternami trans aparatu Golgiego (TGN, ang. trans Golgi network), a endosomami. Skutkuje to wspomnianą wcześniej sekrecją CPY [1] wynikającą z defektu transportu powrotnego z endosomów do TGN białka Vps10, receptora dla CPY [54]. Vps13 wpływa także na transport proteazy Kex2, modulując odczytywanie zawartych w C-końcu tego białka sygnałów transportu, na sortowanie białka Sna3-GFP w endosomach do wakuoli [11] oraz białka Snc1 w endosomach do błony komórkowej [55]. Ciekawy jest fakt, że te fenotypy transportowe mutanta ops13 $\Delta$ są analogiczne do fenotypów obserwowanych przy braku PI(3)P w komórce, wywołanych mutacjami w genach VPS30 i VPS34, kodujących podjednostki kinazy PI3K klasy III, produkującej PI(3)P z PI. Co więcej, porównanie danych zależności genetycznych z wielkoskalowych analiz wykazuje, że brak VPS13 ma podobne spektrum oddziaływań genetycznych jak brak genów VPS30 lub VPS34 [8]. Wynikać to może z faktu, że PI(3)P wpływa na lokalizację Vps13 [8,12], ale też $\mathrm{z}$ tego, że zdolność wiązania $\mathrm{PI}(3) \mathrm{P}$ przez Vps13 jest istotna dla jego funkcjonowania. Mutacja vps13-I2749R we fragmencie kodującym domenę APT1, powodująca spadek oddziaływania Vps13 z PI(3)P o około 50\%, skutkuje całkowitą utratą funkcjonalności białka [11]. Udział Vps13 w transporcie wydaje się być dość złożony, gdyż doświadczenia in vitro analizujące fuzje homotypową błon aparatu Golgiego lub heterotypową błon aparatu Golgiego i endosomów z użyciem błon wyizolowanych ze szczepu vps13ム wskazują, że Vps13 uczestniczy w obu typach fuzji. Odtworzenie fuzji przez dodanie do takich reakcji wyczyszczonego białka Vps13 świadczy o bezpośrednim udziale Vps13 W fuzji błon. W reakcji fuzji błon Vps13 współdziała z białkiem Cdc31 - centryną, z którą się wiąże. Vps13 izolowane ze szczepu pozbawionego funkcjonalnej centryny nie działa w reakcji fuzji błon [4]. Centryna jest białkiem podobnym do kalmoduliny, wiąże się do innych białek analogicznie jak kalmodulina do motywów IQ w miozynie [56] i zawiera motywy wiązania jonów $\mathrm{Ca}^{2+}$ jak i $\mathrm{Mg}^{2+}$ [57]. Sugeruje to, że centryna działa regulatorowo na inne białka, analogicznie do kalmoduliny. Prawdopodobnym jest, że centryna, tak jak wiązanie PI(3)P, wpływa regulatorowo na Vps13.

Brak Vps13 u drożdży, analogicznie do zmian w komórkach pacjentów z ChAc, powoduje zmiany w organizacji cytoszkieletu aktynowego. Łatki aktynowe, miejsca dynamicznej polimeryzacji aktyny, które w szczepie kontrolnym lokalizują się w rosnącym pączku [58], w szczepie ops13ム są znajdowane w komórkach matecznych [11]. Łatki te normalnie tworzą się pod błoną komórkową, w miejscach gdzie zachodzi endocytoza [59]. Stąd zaburzenia w działaniu cytoszkieletu aktynowego przekładają się na spowolnienie lub zahamowanie endocytozy, co jest obserwowane w mutancie vps13 [11]. Nie wiadomo, w jaki sposób Vps13 przyczynia się do zmian w organizacji cytoszkieletu aktynowego. Badania składu białkowego łatek aktynowych otrzymanych in vitro wykazały obecność w nich białka Vps13, więc może ono tam działać bezpośrednio [60]. Jednak nie wiadomo, do którego z białek cytoszkieletu aktynowego Vps13 się wiąże. Podobnie jak hVps13A, Vps13 z drożdży oddziałuje z aktyną [11], więc lokalizacja w łatkach może być utrzymywana przez wiązanie się do aktyny.

Kolejnym fenotypem mutanta pozbawionego Vps13 u drożdży, który jest analogiczny do fenotypu opisanego dla komórek pozbawionych hVps13A, C lub D, jest zmiana w funkcjonowaniu mitochondriów. U drożdży, w mutancie ops13 $\Delta$ obserwowany jest zwiększony poziom ucieczki mitochondrialnego DNA do jądra, świadczący o niestabilności mitochondriów. Konsekwencją tych zmian jest pobudzenie degradacji mitochondriów na drodze mitofagii [61]. Pomimo zaburzonej homeostazy mitochondriów, mutant vps13山 nie wykazuje defektu wzrostu w warunkach wymagających mitochondrialnego oddychania tj. na pożywkach z niefermentowanym źródłem węgla np. glicerolem [61].

Udział Vps13 w różnych procesach komórkowych powinien wiązać się z obecnością Vps13 w różnych lokalizacjach, jak mitochondria, aparat Golgiego, endosomy, wakuola. W obecności glukozy w pożywce, przeważa lokalizacja Vps13 w cytoplazmie, na endosomach i peroksysomach [8,11]. Jednakże, w kilku pracach pokazano obecność Vps13 w miejscach kontaktu błon. Miejsca kontaktu błon są to struktury, w których błony dwóch różnych organelli zbliżone są do siebie na odległość 10-30 nm [62]. Struktury te mają charakter dynamiczny, powstają i rozpadają się w zależności od zapotrzebowania komórki, a błony $\mathrm{w}$ tych strukturach nie ulegają fuzji. Białka uczestniczące $\mathrm{w}$ formowaniu się miejsc kontaktu błon pełnią także inne funkcje poza funkcją strukturalną. Biorą udział w procesach takich jak: transport lipidów między błonami, przekazywanie sygnałów, czy wymiana jonów między organellami. Opisanie udziału Vps13 w tego typu miejscach kontaktu błon zapoczątkowały prace nad miejscami kontaktu błon mitochondriów z ER tzw. ERMES (ang. ER mitochondria encounter structure). Odkryto, że mutant mmm1 pozbawiony jednego z białek ERMES, który nie rośnie na pożywkach z niesfermentowanym źródłem węgla, akumuluje mutacje w genie VPS13. Mutacje te pozwalają żyć mutantowi $m m m 1 \Delta$ na pożywkach z glicerolem [63] oraz 
znoszą wewnątrzkomórkową akumulację żelaza związaną z brakiem ERMES. Supresja akumulacji żelaza jest specyficzna dla mutanta $m m m 1 \Delta$, nie występuje dla innych mutantów akumulujących żelazo w komórkach [64]. Vps13 nie jest elementem ERMES, jednakże lokalizuje się na powierzchni mitochondriów w warunkach nadprodukcji białka mitochondrialnego Mcp1, z którym Vps13 fizycznie się wiąże [8]. Oddziaływanie Vps13-Mcp1 jest niezbędne do supresji mutacji mmm1 mentami ścieżki obejścia braku ERMES, poprzez zmienione działanie miejsc kontaktu błon mitochondriów z wakuolą [8]. Badania lokalizacji Vps13 wykazały, że jest ona zmienna. W zależności od rodzaju źródła węgla w podłożu Vps13 znajduje się w różnego rodzaju miejscach kontaktu błon: wakuoli z mitochondriami tzw. v-CLAMP (ang. vacuole and mitochondria patch), endosomów z mitochondriami, jak i wakuoli z błoną jądrową tzw. NVJ (ang. nuclear vacuolar junction) $[61,63]$. Zaobserwowano również obecność Vps13 w strukturach zawierających marker ciałek lipidowych - białko Erg6 [65], co może być związane z udziałem NVJ w biogenezie ciałek lipidowych [66]. Tę zmienną lokalizację Vps13 zależną od warunków środowiska można interpretować dwojako. Vps13 determinuje, które miejsca kontaktu błon się tworzą i jest w nich obecne lub miejsca kontaktu błon tworzą się najpierw, a Vps13 jest do nich rekrutowane. Powstaje też pytanie, czy Vps13 pełni tylko funkcję strukturalną $\mathrm{w}$ tych miejscach, czy uczestniczy aktywnie w przenoszeniu metabolitów, np. lipidów. Stwierdzono, że mutant vps13 $\Delta$ wykazuje zmniejszony poziom PI(4)P w błonach tworzących się spor, a w komórkach szczurzych PC12 pozbawionych genu VPS13A poziom PI(4)P jest obniżony w błonie komórkowej i w błonach aparatu Golgiego [45]. Sugeruje to, że Vps13 mógłby transportować PI(4)P lub jego prekursor PI. Jednakże brak Vps13 może zaburzać transport innego metabolitu, a obserwowany fenotyp jest zmianą kompensacyjną. Innym istotnym pytaniem jest, czy Vps13 działa w różnych miejscach, pełniąc tę samą funkcję, czy też wykorzystując różne domeny uczestniczy niezależnie $\mathrm{w}$ wielu procesach? Istnieją przesłanki popierające obie hipotezy. Wiele wskazuje jednak na to, że białko Vps13 może pełnić jedną funkcję, w różnych miejscach kontaktu błon tworzonych w zależności od warunków wzrostu. Funkcja ta polegać by mogła na przenoszeniu jednego i tego samego metabolitu między organellami, np. lipidu, co wpływałoby na regulację procesów tam zachodzących. Oprócz lokalizacji Vps13 w miejscach kontaktu błon, przesłanką popierającą tę hipotezę jest podobieństwo w budowie domenowej Vps13 do białek transportujących lipidy: białek OSBP/ORP przenoszących sterole, czy białek CERT transportujących sfingolipidy. Jest to obecność domeny PH-like wiążącej lipidy, oraz motywu FFAT niezbędnego do interakcji z białkami VAP, uczestniczącymi w tworzeniu miejsc kontaktu błon z udziałem ER (Ryc. 1). Poza podobieństwami w budowie Vps13 do białek transportujących lipidy, na pełnienie funkcji transportowej w miejscach kontaktu błon wskazuje supresja wybranych fenotypów mutanta drożdży pozbawionego białka Vps13 przez nadprodukcję fragmentu białka Myo3 [67]. U drożdży miozyna Myo3 wraz z białkami ORP (Osh2/3), uczestniczy w tworzeniu miejsc kontaktu błon ER z błoną komórkową [68]. Wsparciem hipotezy o pojedynczej funkcji Vps13 jest też spostrzeżenie, że jest możliwość wytłumaczenia wszystkich fenotypów związanych z brakiem Vps13 jego wpływem na dystrybucję $\mathrm{w}$ komórce jednego lipidu.

\section{KWAS FOSFATYDOWY A POTENCJALNA FUNKCJA VPS13}

Co wspólnego jest we wszystkich fenotypach związanych z brakiem Vps13? Środkowa część i C-końcowy fragment białka Vps13 mogą ustanawiać połączenia błon dzięki motywowi FFAT oraz domenom SHR_BD, APT1 i PH-like. Tak więc potencjalnie N-końcowy fragment Vps13 mógłby zawierać domenę transportującą lipidy między błonami (Ryc. 2). Badanie wiązania lipidów wykazało, że fragment ten oddziałuje z PA, PI(4)P oraz PI $(4,5) \mathrm{P}_{2}$ [4]. Analiza fenotypów związanych z brakiem Vps13 i procesów regulowanych przez różne lipidy sugeruje, że lipidem przenoszonym przez Vps13 mógłby być PA. PA syntetyzowany jest $\mathrm{z}$ kwasu lizofosfatydowego (LPA) w ER i w komórce pełni rolę zarówno strukturalną jak i sygnałową. Stanowi on kluczowy związek pośredni w syntezie glicerofosfolipidów i triacylogliceroli oraz bierze udział w regulacji wielu procesów, w tym m. in. transportu pęcherzykowego i organizacji cytoszkieletu aktynowego (Ryc. 3). Oprócz tego PA uważany jest za jeden z czynników niezbędnych w rozwoju neuronalnym [69]. Zaburzenia w dystrybucji PA w komórce mogłyby prowadzić do zachwiania homeostazy lipidów oraz zmian w funkcjonowaniu neuronów.

U drożdży, PA w błonach ER odpowiada za regulację biosyntezy glicerofosfolipidów $\mathrm{m}$. in. przez wiązanie represora transkrypcji Opi1. W warunkach niedoboru inozytolu, Opi1 wiąże się do białka ER - Scs2 i do PA [70]. Nagromadzenie inozytolu powoduje wzrost produkcji PI z PA, a co za tym idzie zmniejszenie się puli PA w błonie ER, co prowadzi do oddysocjowania białka Opi1. Uwolniony czynnik Opi1 hamuje ekspresję genu syntazy inozytolu i poziom inozytolu spada [70]. Jeżeli nasza hipoteza jest prawdziwa i Vps13 transportuje PA z błon ER, to brak Vps13 powinien powodować nagromadzenie się PA w ER, przez co zwiększone byłoby oddziaływanie Opi1 z ER i w konsekwencji produkcja inozytolu by wzrosła. Rzeczywiście mutant

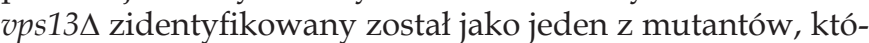
re nadprodukują inozytol i wydzielają go do podłoża [71]. Za wpływem Vps13 na rozmieszczenie PA w komórce przemawia lokalizacja Vps13 w miejscach kontaktu błon -NVJ, które uczestniczą w tworzeniu ciałek lipidowych [66], w których znajdują się enzymy wykorzystujące PA do syntezy triacyloglicerolu. Vps13 lokalizuje się też w strukturach zawierających enzym szlaku biosyntezy ergosterolu Erg6 [65] będący markerem wszystkich ciałek lipidowych, również tych zlokalizowanych przy NVJ [72]. Możliwe jest więc, że Vps13 dostarcza PA do szlaku biosyntezy trójglicerydów.

Wiele fenotypów związanych z brakiem białek Vps13 jest powiązanych $\mathrm{z}$ zaburzeniami w fuzji błon, jak obniżona sekrecja insuliny przy braku hVps13C oraz spadek uwalniania dopaminy ze szczurzych komórek PC12 pozbawionych Vps13A. PA powstaje nie tylko de novo, ale również na skutek działania fosfolipazy D (Pld1) na fosfatydylocholinę. Zahamowanie powstawania PA na drodze zależnej od Pld1 
A

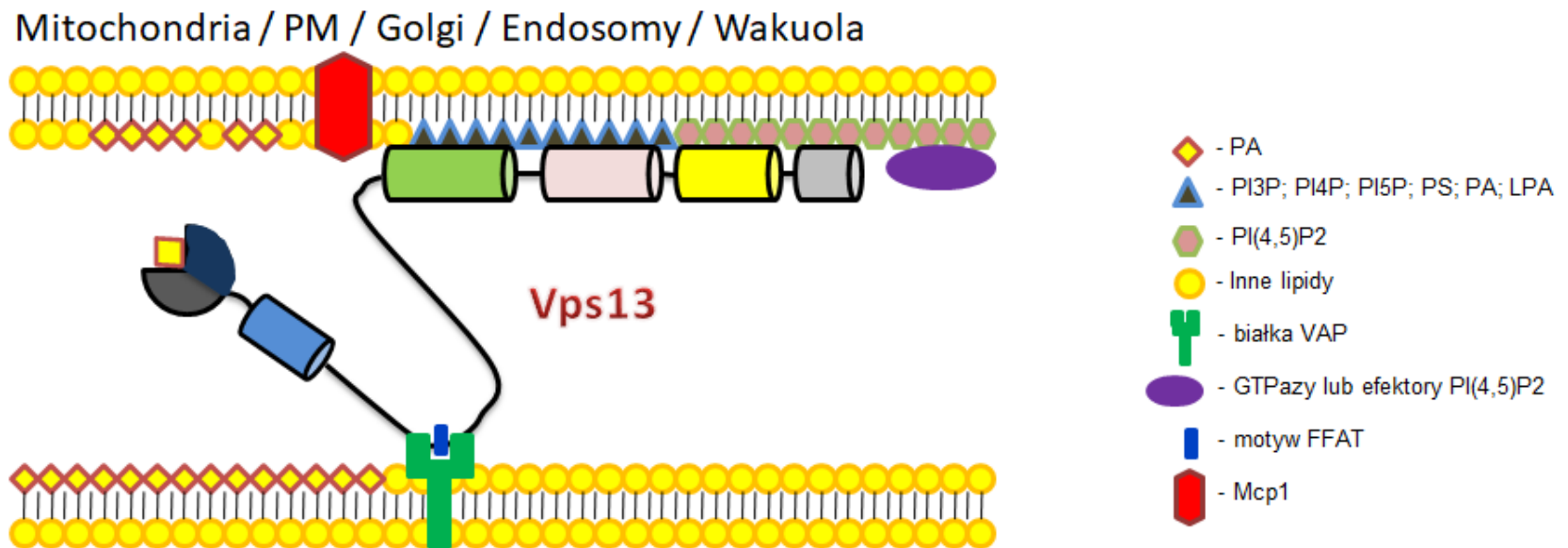

ER

B

PM i inne błony

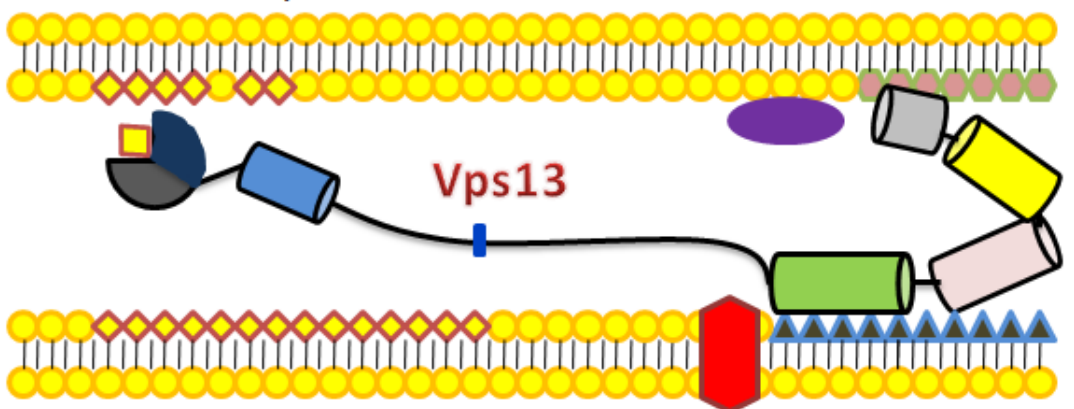

Mitochondria / Endosomy / Wakuola

Rycina 2. Hipotetyczny model działania Vps13 jako przenośnika PA w miejscach kontaktu błon między ER, a błonami innych organelli (A) i między błonami różnych organelli (B)

upośledza fuzje błon pęcherzyków wydzielniczych z błoną komórkową, co prowadzi do obniżonej wydajności egzocytozy [73]. Mechanizm, w wyniku którego PA promuje fuzje błon, jest nadal dyskutowany. Może on być związany ze zdolnością PA do zakrzywiania błony, która ma ulec fuzji [73], ewentualnie mógłby uczestniczyć w rekrutowaniu białek niezbędnych w procesie fuzji błon. Ponadto, w mu-
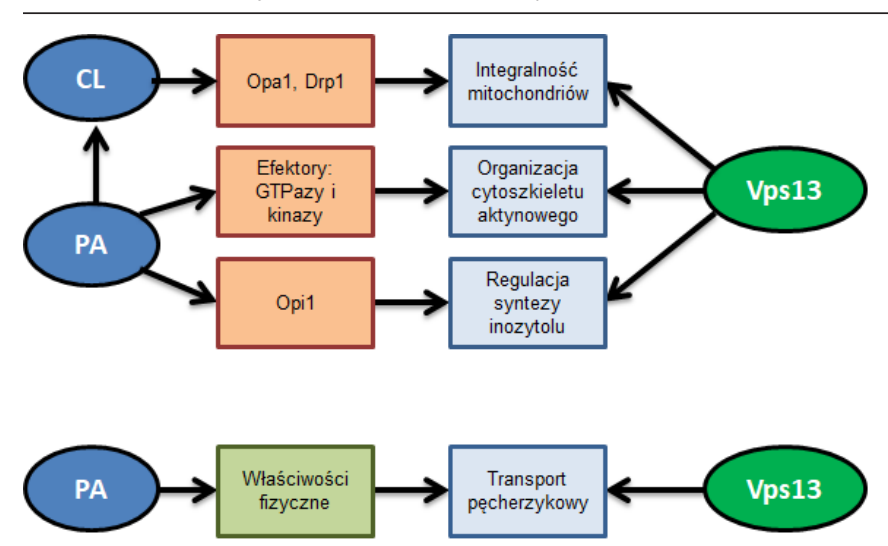

Rycina 3. Procesy regulowane przez PA i przez białko Vps13. tancie vps13 drożdży obserwuje się zaburzenia w procesie endocytozy $[65,67]$, a PA odgrywa rolę $\mathrm{w}$ tym procesie na etapie uwalniania pęcherzyków endocytarnych z błony komórkowej. Dynamina, GTPaza niezbędna do uwolnienia pęcherzyków, wiąże się z błoną w obecności m.in. PA [74]. Podobnie wysoki poziom PA w błonach aparatu Golgiego wspiera wzmożone formowanie pęcherzyków transportujących z tego organellum [75].

Wpływ Vps13 na organizację cytoszkieletu aktynowego można również tłumaczyć udziałem w transporcie PA. PA wpływa na dynamikę przebudowy cytoszkieletu aktynowego przez wiązanie i reguluje GTPaz z rodziny Rho, przez zmianę ich lokalizacji lub przez wpływ na białka je regulujące [76]. PA regulacje też kinazy białkowe np. aktywuje kinazę Pak inicjującą reorganizację cytoszkieletu aktynowego przez działanie m.in. na miozyny typu II, kinazę LIM lub kompleks Arp2/3 [77,78]. Przez PA aktywowane są także kinazy $\mathrm{z}$ rodziny PIPKI generujące $\mathrm{PI}(4,5) \mathrm{P}_{2}$, fosfolipid pełniący kluczową rolę $\mathrm{w}$ reorganizacji cytoszkieletu aktynowego [79]. PA oddziałuje również bezpośrednio z niektórymi białkami cytoszkieletu aktynowego np. winkuliną $[80,81]$. Tak więc zmiany w transporcie PA mogą zmieniać organizację cytoszkieletu aktynowego. 
Fenotypy mitochondrialne opisane $\mathrm{w}$ badaniach nad białkami Vps13 też mogą być związane z udziałem Vps13 w transporcie PA do mitochondriów. Zakłada się, że PA transportowany jest $\mathrm{z}$ ER do mitochondriów przez strukturę ERMES [82]. Jednakże syntetyczna letalność spowodowana brakiem białka Vps13 i jednego z białek tworzących ERMES ,np. Mmm1, sugerować może, że mitochondria importuja PA na dwa sposoby. Twierdzenie to wspierają również badania pokazujące, że brak kompleksu ERMES nie zaburza całkowicie wymiany lipidów między błonami ER i mitochondriów $[83,84]$. PA jest istotny dla mitochondriów jako prekursor w procesie biosyntezy kardiolipiny (CL), fosfolipidu unikalnego dla tego organellum. CL i PA kontrolują podziały i fuzje mitochondriów [85]. CL jest niezbędna do utrzymania kompleksów łańcucha oddechowego i kompleksów zaangażowanych $\mathrm{w}$ import białek do mitochondriów. U drożdży brak CL prowadzi do redukcji potencjału błonowego w mitochondriach, niestabilności kompleksów łańcucha oddechowego oraz zaburzenia importu białek do mitochondriów [86-91]. W mutancie pozbawionym aktywnej syntazy kardiolipiny obserwuje się też utratę mitochondrialnego DNA [92]. Wiele z tych fenotypów opisano również dla komórek pozbawionych kompleksu ERMES $[93,94]$. Wpływ na te procesy ma też $\mathrm{w}$ pewnym stopniu Vps13 i dlatego przy jego braku obserwuje się zwiększoną ucieczkę mitochondrialnego DNA i zwiekszoną mitofagię [61].

Podobieństwo fenotypów oraz oddziaływań genetycznych pomiędzy vps13 $\Delta$, a brakiem kompleksów PI3 kinazy klasy III (delecjami genów VPS30, VPS34), także może być tłumaczone udziałem Vps13 w dystrybucji PA. Kinazy PI3K klasy III biorą udział w aktywacji fosfolipazy D która, jak wcześniej wspomniano, wpływa na fuzje błon [95]. Ścieżka otrzymywania PA przez działanie fosfolipazy może dodatkowo wpływać m.in. na aktywację kinazy mTOR [95]. mTOR jest kinazą regulowaną przez składniki pokarmowe, czynniki wzrostowe i stres; wchodzi w skład dwóch kompleksów TORC1 i TORC2 [96]. Pobudzona ścieżka kinazy TORC2 indukuje zmiany w cytoszkielecie aktynowym [97] i w syntezie lipidów [98] m. in. w odpowiedzi na stres błony komórkowej, co prowadzi do zmian w składzie i właściwościach błony komórkowej [99]. Komórki drożdży pozbawione Vps13 nieodpowiednio reagują na stres błony komórkowej i nie są w stanie sobie z nim poradzić [67], co mogłoby wiązać się z obniżoną aktywacją kinazy TORC2.

Wymienione powyżej spostrzeżenia, dotyczące analogii między niedoborem lub nieprawidłową dystrybucją PA, a brakiem białek Vps13 są oparte na analizie danych literaturowych. Hipoteza udziału białek Vps13 w dystrybuowaniu PA wymaga sprawdzenia eksperymentalnego. Nie można też wykluczyć, że Vps13 przez tworzenie miejsc kontaktu błon wpływa pośrednio na transport innych kluczowych cząsteczek.

\section{PODSUMOWANIE}

Parafrazując cytat z Chatki Puchatka: „The more he looked inside, the more Piglet wasn't there." („Im bardziej Puchatek zaglądał do środka, tym bardziej Prosiaczka tam nie było.") możemy powiedzieć, że im więcej prowadzimy badań nad białkami Vps13 tym mniej je rozumiemy, gdyż rodzi się coraz więcej pytań. Dlaczego przy braku hVps13A zmiany dotykają głównie komórek nerwowych i czerwonych krwinek? Dlaczego brak białek hVps13 B-D nie wpływa na krwinki? Na ile białka Vps13 mogą się zastępować? Jaka jest kaskada zdarzeń prowadząca od braku białka Vps13 do objawów klinicznych? Który proces powinien być celem terapii? Prace $\mathrm{w}$ wielu laboratoriach ukierunkowane są na poszukiwanie odpowiedzi na te pytania. Badania skupiające się na poszukiwaniu funkcji białek Vps13 mają kluczowe znaczenie. Jej poznanie pozwoli na opracowanie terapii celowanej, która mogłaby doprowadzić do opóźnienia postępów choroby i poprawy jakości życia pacjentów z chorobami wywołanymi brakiem białek Vps13. Ponadto wyniki tych badań rozszerzają naszą wiedzę o podstawowych procesach zachodzących w komórkach.

\section{PIŚMIENNICTWO}

Informacja: Po przyjęciu niniejszej pracy do druku ukazała się publikacja pokazująca, że N-końcowy fragment białka Vps13 (1-1350) wiąże glicerofosfolipidy, w tym PA, i przenosi je między liposomami (Kumar et al., (2018) J Cell Biol 217: 3625-3639).

1. Bankaitis VA, Johnson LM, Emr SD (1986) Isolation of yeast mutants defective in protein targeting to the vacuole. Proc Natl Acad Sci USA 83: 9075-9079

2. Velayos-Baeza A, Vettori A, Copley RR, Dobson-Stone C, Monaco AP (2004) Analysis of the human VPS13 gene family. Genomics 84: 536549

3. Muñoz-Braceras S, Calvo R, Escalante R (2015) TipC and the chorea-acanthocytosis protein VPS13A regulate autophagy in Dictyostelium and human HeLa cells. Autophagy 11: 918-927

4. De M, Oleskie AN, Ayyash M, Dutta S, Mancour L, Abazeed ME, Brace EJ, Skiniotis G, Fuller RS (2017) The Vps13p-Cdc31p complex is directly required for TGN late endosome transport and TGN homotypic fusion. J Cell Biol 216: 425-439

5. Hayashi T, Kishida M, Nishizawa Y, Iijima M, Koriyama C, Nakamura M, Sano A, Kishida S (2012) Subcellular localization and putative role of VPS13A/chorein in dopaminergic neuronal cells. Biochem Biophys Res Commun 419: 511-516

6. Murphy SE, Levine TP (2016) VAP, a Versatile Access Point for the Endoplasmic Reticulum: Review and analysis of FFAT-like motifs in the VAPome. Biochim Biophys Acta 1861: 952-961

7. Koizumi K, Gallagher KL (2013) Identification of SHRUBBY, a SHORT-ROOT and SCARECROW interacting protein that controls root growth and radial patterning. Development 140:1292-1300

8. John Peter AT, Herrmann B, Antunes D, Rapaport D, Dimmer KS, Kornmann B (2017) Vps13-Mcp1 interact at vacuole-mitochondria interfaces and bypass ER-mitochondria contact sites. J Cell Biol 216: 3219-3229

9. Xu Z, Dooner HK (2006) The maize aberrant pollen transmission 1 gene is a SABRE/KIP homolog required for pollen tube growth. Genetics 172: 1251-1261

10. Kaminska J, Rzepnikowska W, Polak A, Flis K, Soczewka P, Bala K, Sienko M, Grynberg M, Kaliszewski P, Urbanek A, Ayscough K, Zoladek T (2016) Phosphatidylinositol-3-phosphate regulates response of cells to proteotoxic stress. Int J Biochem Cell Biol 79: 494-504

11. Rzepnikowska W, Flis K, Kaminska J, Grynberg M, Urbanek A, Ayscough KR, Zoladek T (2017) Amino acid substitution equivalent to human chorea-acanthocytosis I2771R in yeast Vps13 protein affects its binding to phosphatidylinositol 3-phosphate. Hum Mol Genet 26: $1497-1510$ 
12. Rzepnikowska W, Flis K, Muñoz-Braceras S, Menezes R, Escalante R, Zoladek T (2017) Yeast and other lower eukaryotic organisms for studies of Vps13 proteins in health and disease. Traffic 18: 711-719

13. Fidler DR, Murphy SE, Courtis K, Antonoudiou P, El-Tohamy R, Ient J, Levine TP (2016) Using HHsearch to tackle proteins of unknown function: A pilot study with PH domains. Traffic 17: 1214-1226

14. Scheffzek K, Welti S (2012) Pleckstrin homology (PH) like domains versatile modules in protein-protein interaction platforms. FEBS Lett 586: 2662-2673

15. Anding AL, Wang C, Chang TK, Sliter DA, Powers CM, Hofmann K, Youle RJ, Baehrecke EH (2018) Vps13D encodes a ubiquitin-binding protein that is required for the regulation of mitochondrial size and clearance. Curr Biol 28: 287-295.e286

16. Ueno S, Maruki Y, Nakamura M, Tomemori $Y$, Kamae K, Tanabe H, Yamashita Y, Matsuda S, Kaneko S, Sano A (2001) The gene encoding a newly discovered protein, chorein, is mutated in chorea-acanthocytosis. Nat Genet 28: 121-122

17. Kolehmainen J, Black GC, Saarinen A, Chandler K, Clayton-Smith J, Träskelin AL, Perveen R, Kivitie-Kallio S, Norio R, Warburg M, Fryns JP, de la Chapelle A, Lehesjoki AE (2003) Cohen syndrome is caused by mutations in a novel gene, $\mathrm{COH} 1$, encoding a transmembrane protein with a presumed role in vesicle-mediated sorting and intracellular protein transport. Am J Hum Genet 72: 1359-1369

18. Dulski J, Sołtan W, Schinwelski M, Rudzińska M, Wójcik-Pędziwiatr M, Wictor L et al. (2016) Clinical variability of neuroacanthocytosis syndromes-a series of six patients with long follow-up. Clin Neurol Neurosurg 147: 78-83

19. Tomiyasu A, Nakamura M, Ichiba M, Ueno S, Saiki S, Morimoto M et al. (2011) Novel pathogenic mutations and copy number variations in the VPS13A gene in patients with chorea-acanthocytosis. Am J Med Genet B Neuropsychiatr Genet 156B: 620-631

20. Karol J, Agnieszka P, Andrzej K (2010) Choreoakantocytoza - przypadek kliniczny. Aktualn Neurol 10:118 - 22

21. Rafałowska J, Drac H, Jamrozik Z (1996) Neuroacanthocytosis. Review of literature and case report. Folia Neuropathol 34: 178-183

22. Lang F, Pelzl L, Schöls L, Hermann A, Föller M, Schäffer TE, Stournaras C (2017) Neurons, erythrocytes and beyond - the diverse functions of chorein. Neurosignals 25: 117-126

23. Peikert K, Danek A, Hermann A (2017) Current state of knowledge in Chorea-Acanthocytosis as core Neuroacanthocytosis syndrome. Eur J Med Genet doi: 10.1016/j.ejmg.2017.12.007

24. Tomemori Y, Ichiba M, Kusumoto A, Mizuno E, Sato D, Muroya S, Nakamura M, Kawaguchi H, Yoshida H, Ueno S, Nakao K, Nakamura K, Aiba A, Katsuki M, Sano A (2005) A gene-targeted mouse model for chorea-acanthocytosis. J Neurochem 92: 759-766

25. Cohen MM, Hall BD, Smith DW, Graham CB, Lampert KJ (1973) A new syndrome with hypotonia, obesity, mental deficiency, and facial, oral, ocular, and limb anomalies. J Pediatr 83: 280-284

26. Wang H, Falk MJ, Wensel C, Traboulsi EI (2006) Cohen syndrome. GeneReviews ${ }^{\circledast}$ Internet.

27. Seifert W, Kühnisch J, Maritzen T, Lommatzsch S, Hennies HC, Bachmann S, Horn D, Haucke V (2015) Cohen syndrome-associated protein $\mathrm{COH} 1$ physically and functionally interacts with the small GTPase RAB6 at the Golgi complex and directs neurite outgrowth. J Biol Chem 290: 3349-3358

28. Yu TW, Chahrour MH, Coulter ME, Jiralerspong S, Okamura-Ikeda $\mathrm{K}$, Ataman B, Schmitz-Abe K, Harmin DA, Adli M, Malik AN, D'Gama AM, Lim ET, Sanders SJ, Mochida GH, Partlow JN, Sunu CM et al. (2013) Using whole-exome sequencing to identify inherited causes of autism. Neuron 77: 259-273

29. Koshimizu E, Miyatake S, Okamoto N, Nakashima M, Tsurusaki Y, Miyake N, Saitsu H, Matsumoto N (2013) Performance comparison of bench-top next generation sequencers using microdroplet PCR-based enrichment for targeted sequencing in patients with autism spectrum disorder. PLoS One 8: e74167

30. Lesage S, Drouet V, Majounie E, Deramecourt V, Jacoupy M, Nicolas A, Cormier-Dequaire F, Hassoun SM, Pujol C, Ciura S, Erpapazoglou Z, Usenko T, Maurage CA, Sahbatou M, Liebau S et al. (PDG) FPsDGS,
(IPDGC) IPsDGC (2016) Loss of VPS13C function in autosomal-recessive parkinsonism causes mitochondrial dysfunction and increases PINK1/Parkin-dependent mitophagy. Am J Hum Genet 98: 500-513

31. Seong E, Insolera R, Dulovic M, Kamsteeg EJ, Trinh J, Brüggemann N, Sandford E, Li S, Ozel AB, Li JZ, Jewett T, Kievit AJA, Münchau A, Shakkottai V, Klein C, Collins C, Lohmann K, van de Warrenburg BP, Burmeister M (2018) Mutations in VPS13D lead to a new recessive ataxia with spasticity and mitochondrial defects. Ann Neurol doi: 10.1002/ana.25220

32. Gauthier J, Meijer IA, Lessel D, Mencacci NE, Krainc D, Hempel M, Tsiakas K, Prokisch H, Rossignol E, Helm MH, Rodan LH, Karamchandani J, Carecchio M, Lubbe SJ, Telegrafi A, Henderson LB, Lorenzo K, Wallace SE, Glass IA, Hamdan FF, Michaud JL, Rouleau GA, Campeau PM (2018) Recessive mutations in PVPS13D cause childhood onset movement disorders. Ann Neurol doi: 10.1002/ana.25204

33. Sakimoto H, Nakamura M, Nagata O, Yokoyama I, Sano A (2016) Phenotypic abnormalities in a chorea-acanthocytosis mouse model are modulated by strain background. Biochem Biophys Res Commun 472: 118-124

34. Kurano Y, Nakamura M, Ichiba M, Matsuda M, Mizuno E, Kato M, Agemura A, Izumo S, Sano A (2007) In vivo distribution and localization of chorein. Biochem Biophys Res Commun 353: 431-435

35. Kurano Y, Nakamura M, Ichiba M, Matsuda M, Mizuno E, Kato M, Izumo S, Sano A (2006) Chorein deficiency leads to upregulation of gephyrin and GABA(A) receptor. Biochem Biophys Res Commun 351: 438-442

36. Honisch S, Fehrenbacher B, Lebedeva A, Alesutan I, Castor T, Alkahtani S, Alarifi S, Schaller M, Stournaras C, Lang F (2015) Chorein sensitive dopamine release from pheochromocytoma (PC12) Cells. Neurosignals $23: 1-10$

37. Föller M, Hermann A, Gu S, Alesutan I, Qadri SM, Borst O, Schmidt EM, Schiele F, vom Hagen JM, Saft C, Schöls L, Lerche H, Stournaras C, Storch A, Lang F (2012) Chorein-sensitive polymerization of cortical actin and suicidal cell death in chorea-acanthocytosis. FASEB J 26: 1526-1534

38. Shiokawa N, Nakamura M, Sameshima M, Deguchi A, Hayashi T, Sasaki N, Sano A (2013) Chorein, the protein responsible for chorea-acanthocytosis, interacts with $\beta$-adducin and $\beta$-actin. Biochem Biophys Res Commun 441: 96-101

39. Honisch S, Gu S, Vom Hagen JM, Alkahtani S, Al Kahtane AA, Tsapara A, Hermann A, Storch A, Schöls L, Lang F, Stournaras C (2015) Chorein sensitive arrangement of cytoskeletal architecture. Cell Physiol Biochem 37: 399-408

40. Sasaki N, Nakamura M, Kodama A, Urata Y, Shiokawa N, Hayashi T, Sano A (2016) Chorein interacts with a-tubulin and histone deacetylase 6 , and overexpression preserves cell viability during nutrient deprivation in human embryonic kidney 293 cells. FASEB J 30: 3726-3732

41. Basquin C, Sauvonnet N (2013) Phosphoinositide 3-kinase at the crossroad between endocytosis and signaling of cytokine receptors. Commun Integr Biol 6: e24243

42. Rotty JD, Wu C, Bear JE (2013) New insights into the regulation and cellular functions of the ARP2/3 complex. Nat Rev Mol Cell Biol 14 $7-12$

43. Yu W, Honisch S, Schmidt S, Yan J, Schmid E, Alkahtani S, AlKahtane AA, Alarifi S, Stournaras C, Lang F (2016) Chorein sensitive Orai1 expression and store operated Ca2+ entry in rhabdomyosarcoma cells. Cell Physiol Biochem 40: 1141-1152

44. Pelzl L, Elsir B, Sahu I, Bissinger R, Singh Y, Sukkar B, Honisch S, Schoels L, Jemaà M, Lang E, Storch A, Hermann A, Stournaras C, Lang F (2017) Lithium sensitivity of store operated $\mathrm{Ca}^{2+}$ entry and survival of fibroblasts isolated from Chorea-Acanthocytosis patients. Cell Physiol Biochem 42: 2066-2077

45. Park JS, Halegoua S, Kishida S, Neiman AM (2015) A conserved function in phosphatidylinositol metabolism for mammalian Vps13 family proteins. PLoS One 10: e0124836

46. De Franceschi L, Tomelleri C, Matte A, Brunati AM, Bovee-Geurts PH, Bertoldi M, Lasonder E, Tibaldi E, Danek A, Walker RH, Jung HH, Bader B, Siciliano A, Ferru E, Mohandas N, Bosman GJ (2011) Eryth- 
rocyte membrane changes of chorea-acanthocytosis are the result of altered Lyn kinase activity. Blood 118: 5652-5663

47. Seifert W, Kühnisch J, Maritzen T, Horn D, Haucke V, Hennies HC (2011) Cohen syndrome-associated protein, COH1, is a novel, giant Golgi matrix protein required for Golgi integrity. J Biol Chem 286: 37665-37675

48. Duplomb L, Duvet S, Picot D, Jego G, El Chehadeh-Djebbar S, Marle N, Gigot N, Aral B, Carmignac V, Thevenon J, Lopez E, Rivière JB, Klein A, Philippe C, Droin N, Blair E, Girodon F, Donadieu J, Bellanné-Chantelot C, Delva L, Michalski JC, Solary E, Faivre L, Foulquier F, Thauvin-Robinet C (2014) Cohen syndrome is associated with major glycosylation defects. Hum Mol Genet 23: 2391-2399

49. Ramseyer VD, Kimler VA, Granneman JG (2018) Vacuolar protein sorting $13 \mathrm{C}$ is a novel lipid droplet protein that inhibits lipolysis in brown adipocytes. Mol Metab 7: 57-70

50. Yang RY, Xue H, Yu L, Velayos-Baeza A, Monaco AP, Liu FT (2016) Identification of VPS13C as a galectin-12-binding protein that regulates galectin-12 protein stability and adipogenesis. PLoS One 11: e0153534

51. Strawbridge RJ, Dupuis J, Prokopenko I, Barker A, Ahlqvist E, Rybin D, Petrie JR, Travers ME, Bouatia-Naji N, Dimas AS, Nica A, Wheeler E, Chen H, Voight BF, Taneera J et al (2011) Genome-wide association identifies nine common variants associated with fasting proinsulin levels and provides new insights into the pathophysiology of type 2 diabetes. Diabetes 60: 2624-2634

52. Saxena R, Hivert MF, Langenberg C, Tanaka T, Pankow JS, Vollenweider P, Lyssenko V, Bouatia-Naji N, Dupuis J, Jackson AU, Kao WH, Li M, Glazer NL, Manning AK, Luan J et al. (2010) Genetic variation in GIPR influences the glucose and insulin responses to an oral glucose challenge. Nat Genet 42: 142-148

53. Mehta ZB, Fine N, Pullen TJ, Cane MC, Hu M, Chabosseau P, Meur G, Velayos-Baeza A, Monaco AP, Marselli L, Marchetti P, Rutter GA (2016) Changes in the expression of the type 2 diabetes-associated gene VPS13C in the $\beta$-cell are associated with glucose intolerance in humans and mice. Am J Physiol Endocrinol Metab 311: E488-507

54. Brickner JH, Fuller RS (1997) SOI1 encodes a novel, conserved protein that promotes TGN-endosomal cycling of Kex2p and other membrane proteins by modulating the function of two TGN localization signals. J Cell Biol 139: 23-36

55. Dalton LE, Bean BDM, Davey M, Conibear E (2017) Quantitative high-content imaging identifies novel regulators of Neo1 trafficking at endosomes. Mol Biol Cell 28: 1539-1550

56. Li S, Sandercock AM, Conduit P, Robinson CV, Williams RL, Kilmartin JV (2006) Structural role of Sfilp-centrin filaments in budding yeast spindle pole body duplication. J Cell Biol 173: 867-877

57. Miron S, Durand D, Chilom C, Pérez J, Craescu CT (2011) Binding of calcium, magnesium, and target peptides to Cdc31, the centrin of yeast Saccharomyces cerevisiae. Biochemistry 50: 6409-6422

58. Bi E, Park HO (2012) Cell polarization and cytokinesis in budding yeast. Genetics 191: 347-387

59. Goode BL, Eskin JA, Wendland B (2015) Actin and endocytosis in budding yeast. Genetics 199: 315-358

60. Michelot A, Costanzo M, Sarkeshik A, Boone C, Yates JR, Drubin DG (2010) Reconstitution and protein composition analysis of endocytic actin patches. Curr Biol 20: 1890-1899

61. Park JS, Thorsness MK, Policastro R, McGoldrick LL, Hollingsworth NM, Thorsness PE, Neiman AM (2016) Yeast Vps13 promotes mitochondrial function and is localized at membrane contact sites. Mol Biol Cell 27: 2435-2449

62. Stefan CJ, Manford AG, Emr SD (2013) ER-PM connections: sites of information transfer and inter-organelle communication. Curr Opin Cell Biol 25: 434-442

63. Lang AB, John Peter AT, Walter P, Kornmann B (2015) ER-mitochondrial junctions can be bypassed by dominant mutations in the endosomal protein Vps13. J Cell Biol 210: 883-890

64. Xue Y, Schmollinger S, Attar N, Campos OA, Vogelauer M, Carey MF, Merchant SS, Kurdistani SK (2017) Endoplasmic reticulum-mitochon- dria junction is required for iron homeostasis. J Biol Chem 292: 1319713204

65. Rzepnikowska W (2017) rozprawa doktorska. IBB PAN, Warszawa

66. Hariri H, Rogers S, Ugrankar R, Liu YL, Feathers JR, Henne WM (2018) Lipid droplet biogenesis is spatially coordinated at ER-vacuole contacts under nutritional stress. EMBO Rep 19: 57-72

67. Soczewka P, Kolakowski D, Rzepnikowska W, Smaczynska-de Rooij I, Ayscough KR, Kaminska J, Zoladek T Yeast model based study identified myosin and calcium-dependent calmodulin signalling as a potential target for drug intervention in chorea-acanthocytosis. in revisions.

68. Encinar Del Dedo J, Idrissi FZ, Fernandez-Golbano IM, Garcia P, Rebollo E, Krzyzanowski MK, Grötsch H, Geli MI (2017) ORP-mediated ER contact with endocytic sites facilitates actin polymerization. Dev Cell 43: 588-602.e586

69. Ammar MR, Kassas N, Bader MF, Vitale N (2014) Phosphatidic acid in neuronal development: a node for membrane and cytoskeleton rearrangements. Biochimie 107: 51-57

70. Gaspar ML, Chang YF, Jesch SA, Aregullin M, Henry SA (2017) Interaction between repressor Opilp and ER membrane protein Scs2p facilitates transit of phosphatidic acid from the ER to mitochondria and is essential for. J Biol Chem 292: 18713-18728

71. Hancock LC, Behta RP, Lopes JM (2006) Genomic analysis of the Opiphenotype. Genetics 173: 621-634

72. Athenstaedt K, Zweytick D, Jandrositz A, Kohlwein SD, Daum G (1999) Identification and characterization of major lipid particle proteins of the yeast Saccharomyces cerevisiae. J Bacteriol 181: 6441-6448

73. Zeniou-Meyer M, Zabari N, Ashery U, Chasserot-Golaz S, Haeberlé AM, Demais V, Bailly Y, Gottfried I, Nakanishi H, Neiman AM, Du G, Frohman MA, Bader MF, Vitale N (2007) Phospholipase D1 production of phosphatidic acid at the plasma membrane promotes exocytosis of large dense-core granules at a late stage. J Biol Chem 282: 21746-21757

74. Burger KN, Demel RA, Schmid SL, de Kruijff B (2000) Dynamin is membrane-active: lipid insertion is induced by phosphoinositides and phosphatidic acid. Biochemistry 39: 12485-12493

75. Siddhanta A, Shields D (1998) Secretory vesicle budding from the trans-Golgi network is mediated by phosphatidic acid levels. J Biol Chem 273: 17995-17998

76. Ridley AJ, Hall A (1992) The small GTP-binding protein rho regulates the assembly of focal adhesions and actin stress fibers in response to growth factors. Cell 70: 389-399.

77. Sanders LC, Matsumura F, Bokoch GM, de Lanerolle P (1999) Inhibition of myosin light chain kinase by p21-activated kinase. Science 283 : 2083-2085

78. Vadlamudi RK, Li F, Barnes CJ, Bagheri-Yarmand R, Kumar R (2004) p41-Arc subunit of human Arp2/3 complex is a p21-activated kinase-1-interacting substrate. EMBO Rep 5: 154-160

79. Roach AN, Wang Z, Wu P, Zhang F, Chan RB, Yonekubo Y, Di Paolo G, Gorfe AA, Du G (2012) Phosphatidic acid regulation of PIPKI is critical for actin cytoskeletal reorganization. J Lipid Res 53: 2598-2609

80. Ito S, Richert N, Pastan I (1982) Phospholipids stimulate phosphorylation of vinculin by the tyrosine-specific protein kinase of Rous sarcoma virus. Proc Natl Acad Sci USA 79: 4628-4631

81. Johnson RP, Craig SW (1995) F-actin binding site masked by the intramolecular association of vinculin head and tail domains. Nature 373 261-264

82. Jeong H, Park J, Jun Y, Lee C (2017) Crystal structures of Mmm1 and Mdm12-Mmm1 reveal mechanistic insight into phospholipid trafficking at ER-mitochondria contact sites. Proc Natl Acad Sci USA 114: E9502-E9511

83. Kornmann B, Currie E, Collins SR, Schuldiner M, Nunnari J, Weissman JS, Walter P. (2009) An ER-mitochondria tethering complex revealed by a synthetic biology screen. Science 325: 477-481

84. Nguyen TT, Lewandowska A, Choi JY, Markgraf DF, Junker M, Bilgin M, Ejsing CS, Voelker DR, Rapoport TA, Shaw JM (2012) Gem1 and ERMES do not directly affect phosphatidylserine transport from ER to mitochondria or mitochondrial inheritance. Traffic 13: 880-890 
85. Kameoka S, Adachi Y, Okamoto K, Ijima M, Sesaki H (2018) Phosphatidic acid and cardiolipin coordinate mitochondrial dynamics. Trends Cell Biol 28: 67-76

86. Jiang F, Ryan MT, Schlame M, Zhao M, Gu Z, Klingenberg M, Pfanner N, Greenberg ML (2000) Absence of cardiolipin in the crd1 null mutant results in decreased mitochondrial membrane potential and reduced mitochondrial function. J Biol Chem 275: 22387-22394

87. Koshkin V, Greenberg ML (2000) Oxidative phosphorylation in cardiolipin-lacking yeast mitochondria. Biochem J 347: 687-691

88. Koshkin V, Greenberg ML (2002) Cardiolipin prevents rate-dependent uncoupling and provides osmotic stability in yeast mitochondria. Biochem J 364: 317-322

89. Pfeiffer K, Gohil V, Stuart RA, Hunte C, Brandt U, Greenberg ML, Schägger H (2003) Cardiolipin stabilizes respiratory chain supercomplexes. J Biol Chem 278: 52873-52880

90. Zhang M, Mileykovskaya E, Dowhan W (2002) Gluing the respiratory chain together. Cardiolipin is required for supercomplex formation in the inner mitochondrial membrane. J Biol Chem 277: 43553-43556

91. Zhang M, Mileykovskaya E, Dowhan W (2005) Cardiolipin is essential for organization of complexes III and IV into a supercomplex in intact yeast mitochondria. J Biol Chem 280: 29403-29408

92. Chen S, Liu D, Finley RL, Greenberg ML (2010) Loss of mitochondrial DNA in the yeast cardiolipin synthase $c r d 1$ mutant leads to up-regulation of the protein kinase Swe1p that regulates the G2/M transition. J Biol Chem 285: 10397-10407
93. Sogo LF, Yaffe MP (1994) Regulation of mitochondrial morphology and inheritance by Mdm10p, a protein of the mitochondrial outer membrane. J Cell Biol 126: 1361-1373

94. Berger KH, Sogo LF, Yaffe MP (1997) Mdm12p, a component required for mitochondrial inheritance that is conserved between budding and fission yeast. J Cell Biol 136: 545-553

95. Yoon MS, Du G, Backer JM, Frohman MA, Chen J (2011) Class III PI-3-kinase activates phospholipase D in an amino acid-sensing mTORC1 pathway. J Cell Biol 195: 435-447

96. Jewell JL, Guan KL (2013) Nutrient signaling to mTOR and cell growth. Trends Biochem Sci 38: 233-242

97. Sen B, Xie Z, Case N, Thompson WR, Uzer G, Styner M, Rubin J (2014) mTORC2 regulates mechanically induced cytoskeletal reorganization and lineage selection in marrow-derived mesenchymal stem cells. J Bone Miner Res 29: 78-89

98. Caron A, Richard D, Laplante M (2015) The roles of mTOR complexes in lipid metabolism. Annu Rev Nutr 35: 321-348

99. Berchtold D, Piccolis M, Chiaruttini N, Riezman I, Riezman H, Roux A, Walther TC, Loewith R (2012) Plasma membrane stress induces relocalization of Slm proteins and activation of TORC2 to promote sphingolipid synthesis. Nat Cell Biol 14: 542-547

\title{
Proteins from Vps13 family: from molecular function to pathogenesis of neurodegenerative disorders Joanna Kaminska ${ }^{\bowtie}$, Damian Kolakowski
}

Institute of Biochemistry and Biophysics PAS, 5a Pawińskiego St., 02-106 Warsaw, Poland

e-mail: kaminska@ibb.waw.pl

Key words: rare diseases, neurodegeneration, Vps13 proteins family, chorea-acanthocytosis, Cohen syndrome, membrane contact sites

\begin{abstract}
The Vps (vacuolar protein sorting) group of proteins was identified in yeast Saccharomyces cerevisiae. Among the Vps proteins, there is the Vps13 family, proteins of which are present in organisms from different systematic groups. In yeast there is only one Vps13 protein, while in humans there are four Vps13 family members - hVps13A-D. These are large proteins of characteristic domain structure. Mutations in $h V P S 13$ genes are linked to rare neurodegenerative disorders: chorea-acanthocytosis ( $h V P S 13 A)$, Cohen syndrome $(h V P S 13 B)$, predispose to early onset into Parkinson disease ( $h V P S 13 C)$ and lead to ataxia/spastic paraplegia ( $h V P S 13 D)$. Lack of clear diagnostic criteria and broad spectrum of nonspecific symptoms cause the misdiagnosis of several patients with neurodegeneration and it is difficult to estimate the number of individuals with mutations in $h V P S 13$ genes. The importance of Vps13 family proteins for human health turns interest of research on finding Vps13 protein function, which remains unknown. The research is mostly performed on several experimental models in which deficit of those proteins was acquired by deletions or gene expression silencing, or on cells from patients. Several changes were found in cells lacking $\mathrm{Vps} 13$ proteins on cellular level, such as changes in intracellular protein trafficking between Golgi apparatus, plasma membrane and endosomes, changes in mitochondria functioning and changes in organization of cytoskeletons, mainly actin cytoskeleton. However, it is unknown which alterations are primary and which secondary, compensatory. Recently research done on yeast revealed that Vps13 is a protein of the membrane contact sites, the structures involved in exchange of metabolites between different organelles. Such localization seems to be essential for Vps13 function. Based on literature we propose a hypothesis that Vps13 might actively participate in exchange of the lipids between membranes of organelles in membrane contact sites what could explain most of the phenotypes caused by lack of Vps13 protein.
\end{abstract}

